\title{
CORRELATION OF HbA1C, LIPID PROFILE AND FASTING BLOOD SUGAR AND DURATION OF DIABETES MELLITUS WITH SEVERITY OF DIABETIC RETINOPATHY
}

\author{
D. V. C. Nagasree ${ }^{1}$, Ramakrishna Rachakonda²
}

${ }_{1}^{1}$ Associate Professor, Department of Ophthalmology, NRI Medical College, Chinnakakani, Guntur, Andhra Pradesh, India.

2Professor and HOD, Department of Pulmonary Medicine, NRI Medical College, Chinnakakani, Guntur, Andhra Pradesh, India.

\begin{abstract}
BACKGROUND
ABSTRACT

We have studied patients having diabetic retinopathy attending the Department of Ophthalmology, Katuri Medical College, Guntur in a cross-sectional, hospital-based, non-interventional study.

Aim- To study the prevalence of different parameters like duration of diabetes mellitus, fasting blood sugar at the time of diagnosis of retinopathy, $\mathrm{HbA1c}$, lipid profile and correlate with severity of diabetic retinopathy and assess the statistical significance.

Objective- To identify the important factors that can influence severity of Diabetic retinopathy in our area, in order to identify highrisk patients early, to prevent visual loss.
\end{abstract}

\section{MATERIALS AND METHODS}

The present study is a hospital-based cross-sectional study, which was conducted at our tertiary care centre. We have studied a total of 302 patients diagnosed to have diabetic retinopathy for one and a half years in our tertiary care centre.

\section{RESULTS}

Among the 302 patients taken into the study, 64\% were females and 36\% were males. Diabetic retinopathy predominantly occurred in patients above 50 years of age. HDL $<40 \mathrm{mg} \%$, LDL $>100 \mathrm{mg} \%$ and VLDL $>40 \mathrm{mg} \%$ levels have significant correlation with different grades of retinopathy. This also denotes that these values are related to the severity of diabetic retinopathy. Glycosylated haemoglobin (HbA1c) above 7\%, serum total cholesterol $>200 \mathrm{mg} \%$, serum total triglycerides $>200 \mathrm{mg} \%$ and duration of diabetes mellitus $>9$ years did not correlate with the severity of diabetic retinopathy.

\section{CONCLUSION}

HDL $<40 \mathrm{mg} \%$, LDL > $100 \mathrm{mg} \%$ and VLDL > $40 \mathrm{mg} \%$ levels have significant correlation with different grades of retinopathy. This also denotes that these values are related to the severity of diabetic retinopathy with chi-square test with $p$-value of $<0.05$. HbA1c values and high fasting blood sugar did not correlate with severity of retinopathy.

\section{KEY WORDS}

Diabetic Retinopathy, HbA1c, Lipid Profile, Triglycerides, Cholesterol.

HOW TO CITE THIS ARTICLE: Nagasree DVC, Rachakonda R. Correlation of HbA1c, lipid profile and fasting blood sugar and duration of diabetes mellitus with severity of diabetic retinopathy. J. Evolution Med. Dent. Sci. 2018;7(30):3401-3404, DOI: $10.14260 /$ jemds/2018/767

\section{BACKGROUND}

India is a high burden country of Diabetes with more than 62 million Diabetic individuals $(1,2)$ and as a result Diabetic retinopathy is emerging as an important cause of visual disability reported by World Health Organisation. ${ }^{(3,4)}$

About 5.5 million adult patients with Diabetes have Diabetic retinopathy and 50,000 new cases of blindness occur per year, out of which $50 \%$ are caused by Diabetes, that too mostly by Diabetic retinopathy.(5)

Diabetic retinopathy is a vascular disorder affecting the microvasculature of retina.(2)

Diabetes mellitus is known to produce the microvascular complications, ${ }^{(6)}$ and hyperlipidaemia causes endothelial

'Financial or Other Competing Interest': None.

Submission 03-04-2018, Peer Review 10-07-2018,

Acceptance 16-07-2018, Published 23-07-2018.

Corresponding Author:

D. V. C. Nagasree,

Sanjeevani Hospital,

A1, Ramkuteer Majestic,

3/13, Brodipet, Guntur,

Andhra Pradesh, India.

E-mail: ramakrishna45@yahoo.co.in

DOI: $10.14260 /$ jemds $/ 2018 / 767$

\section{(c) (i) $(9)$}

dysfunction due to reduced bioavailability of Nitric Oxide and breakdown of Blood-Retinal Barrier leading to exudation of serum lipid and lipoproteins, which result in Diabetic retinopathy changes and Diabetic macular oedema formation. $(7,8)$

The established risk factors for development and progression of Diabetic retinopathy include: Type, Duration, Age, Gender, BMI, Glycaemic control, Hypertension, Nephropathy, Smoking, Pregnancy and Serum lipid levels. $(9,10)$

HbA1c is presently the gold standard parameter, which detects the mean blood glucose levels over a period of $6-8$ weeks and predicts the potential angiopathic complications.(11)

The pathogenic mechanisms of microvascular complications are same in Diabetic Retinopathy and Diabetic Nephropathy. (12)

\section{Aims and Objectives}

- To study the relation of Fasting Blood Sugar at the time of Diagnosis, HbA1c and Lipid profile in different grades of Diabetic retinopathy.

- To correlate the severity of Diabetic retinopathy with Fasting Blood Sugars, HBA1C and Lipid profile. 
- To identify the important factors that can influence severity of diabetic retinopathy in our area to identify high-risk patients early to prevent visual loss.

\section{MATERIALS AND METHODS}

\section{Study Type}

The present study is a hospital-based cross-sectional study, which was conducted at our tertiary care centre.

\section{Study Duration}

The research study was conducted from April 2016 to October 2017.

\section{Inclusion Criteria}

1. All the patients diagnosed as Diabetic Retinopathy above 20 years of age.

2. Patients of both sexes are taken into the study.

\section{Exclusion Criteria}

Non-cooperative patients and patients with Diabetic retinopathy, who are seriously ill with other complications.

302 patients of Diabetes mellitus with Retinopathy were included in the study. All the patients with diabetic retinopathy were subjected to dilated fundoscopy with $90+\mathrm{D}$ lens direct ophthalmoscopy and were graded as follows:

- $\quad$ Microaneurysm (s) only- Grade I.

- $\quad$ Mild NPDR- Grade II.

- Moderate NPDR- Grade III.

- $\quad$ Severe NPDR- Grade IV.

- $\quad$ Proliferative DR- Grade V.

These patient's blood samples were assessed biochemically for glycosylated haemoglobin (HBA1C), lipid profile and Fasting Blood Sugar levels. HBA1C was assessed by Ion exchange resin method in a semi-auto chemistry analyser, whereas lipid profile was processed by fully autochemistry analyser.

Statistical Analysis: Descriptive statistics were used to present the findings. Chi-square test of association was used to study the association between severity of retinopathy and different variables under study.

\section{RESULTS}

\begin{tabular}{|c|c|c|c|c|}
\hline $\begin{array}{c}\text { Grade of } \\
\text { Retinopathy }\end{array}$ & Males & Females & Total & \% \\
\hline Grade I & 36 & 48 & 84 & $27.81 \%$ \\
\hline Grade II & 49 & 55 & 104 & $34.44 \%$ \\
\hline Grade III & 43 & 39 & 82 & $27.15 \%$ \\
\hline Grade IV & 08 & 08 & 16 & $5.29 \%$ \\
\hline Grade V & 08 & 08 & 16 & $5.29 \%$ \\
\hline Total & 144 & 158 & 302 & 100 \\
\hline Percentage & $47.68 \%$ & $52.32 \%$ & 302 & 100 \\
\hline \multicolumn{6}{|c|}{ Table 1. Sex Distribution of patients of Diabetic } \\
Retinopathy \\
\hline
\end{tabular}

The Chi-square statistic for female preponderance is 1.61 . The p-value is 0.806991 . The result is not significant at $\mathrm{p}<0.05$.

\begin{tabular}{|c|c|c|}
\hline $\begin{array}{c}\text { Grade of } \\
\text { Retinopathy }\end{array}$ & $\begin{array}{c}\text { DM < 9 Years No. } \\
\text { of Patients }\end{array}$ & DM > 9 Years \\
\hline Grade I & 9 & 75 \\
\hline Grade II & 8 & 96 \\
\hline Grade III & 7 & 75 \\
\hline Grade IV & 1 & 15 \\
\hline Grade V & 1 & 15 \\
\hline Total & $\mathbf{2 5}$ & $\mathbf{2 7 7}$ \\
\hline \multicolumn{2}{|c|}{ Table 2. Duration of Diabetes and Diagnosis of } \\
Retinopathy \\
\hline
\end{tabular}

The Chi-square statistic is 0.8111 . P-value is 0.936949 and the value is not statistically significant for 0.05 .

\begin{tabular}{|c|c|c|c|c|c|}
\hline $\begin{array}{c}\text { Grade of } \\
\text { DR }\end{array}$ & $\begin{array}{c}\text { HbA1c } \\
<\mathbf{7 \%}\end{array}$ & $\begin{array}{c}\text { HbA1c } \\
\mathbf{7 - 9 \%}\end{array}$ & $\begin{array}{c}\text { HbA1c } \\
\mathbf{9 - 1 1 \%}\end{array}$ & $\begin{array}{c}\text { HbA1c } \\
\mathbf{> 1 1 \%}\end{array}$ & Total \\
\hline Grade I & 01 & 29 & 42 & 12 & 84 \\
\hline Grade II & 01 & 45 & 39 & 19 & 104 \\
\hline Grade III & 02 & 37 & 34 & 09 & 82 \\
\hline Grade IV & 01 & 06 & 06 & 03 & 16 \\
\hline Grade V & 01 & 04 & 07 & 04 & 16 \\
\hline Total & 06 & $\mathbf{1 2 1}$ & $\mathbf{1 2 8}$ & $\mathbf{4 7}$ & $\mathbf{3 0 2}$ \\
\hline \multicolumn{7}{|c|}{ Table 3. Diabetic Retinopathy and HbA1c } \\
\hline
\end{tabular}

The Chi-square statistic is 10.751 . P-value is 0.550374 . The result is not significant at $\mathrm{p}$-value $<0.05$.

\begin{tabular}{|c|c|c|c|c|c|}
\hline $\begin{array}{c}\text { Grades of } \\
\text { Retinopathy }\end{array}$ & $\begin{array}{c}\text { FBS }<\mathbf{1 0 0} \\
\text { mg\% }\end{array}$ & $\begin{array}{c}\text { FBS 100- } \\
\mathbf{2 0 0} \mathbf{~ m g \%}\end{array}$ & $\begin{array}{c}\text { FBS 200- } \\
\mathbf{3 0 0} \mathbf{~ m g \%}\end{array}$ & $\begin{array}{c}\text { FBS } \\
\mathbf{> 3 0 0} \\
\mathbf{m g} \%\end{array}$ & Total \\
\hline Grade I & 14 & 24 & 28 & 18 & 84 \\
\hline Grade II & 19 & 33 & 38 & 23 & 103 \\
\hline Grade III & 09 & 26 & 34 & 13 & 82 \\
\hline Grade IV & 04 & 02 & 04 & 6 & 16 \\
\hline Grade V & 03 & 04 & 03 & 6 & 16 \\
\hline
\end{tabular}

Table 4. Fasting Blood Sugar and Grades of Retinopathy

The chi-square statistic is 12.0226 . The $\mathrm{p}$-value is .443867 and the result is statistically not significant at $\mathrm{p}<0.05$.

\section{Lipid Profile and Diabetic Retinopathy}

\begin{tabular}{|c|c|c|c|}
\hline Retinopathy & $\begin{array}{c}\text { LDL > 100 } \mathbf{~ m g \%} \\
\mathbf{2} \mathbf{2 6 6}\end{array}$ & $\begin{array}{c}\text { LDL }<\mathbf{1 0 0} \\
\mathbf{m g \%} \mathbf{- 3 6}\end{array}$ & Total \\
\hline Grade I & 64 & 12 & $\mathbf{8 4}$ \\
\hline Grade II & 88 & 16 & $\mathbf{1 0 4}$ \\
\hline Grade III & 79 & 03 & $\mathbf{8 2}$ \\
\hline Grade IV & 13 & 03 & $\mathbf{1 6}$ \\
\hline Grade V & 14 & 02 & $\mathbf{1 6}$ \\
\hline Table 5. $\mathbf{L D L}>\mathbf{1 0 0} \mathbf{~} \mathbf{m g} \%$ and Diabetic Retinopathy \\
\hline
\end{tabular}

The Chi-square statistic is 13.9401. The p-value is .007489 . The result is significant at $\mathrm{p}<0.05$.

\begin{tabular}{|c|c|c|c|}
\hline Retinopathy & $\begin{array}{c}\text { HDL < 40 mg\% } \\
\mathbf{= 2 4 2}\end{array}$ & $\begin{array}{c}\text { HDL > 40 } \mathbf{~ m g \%} \\
\mathbf{= 6 0}\end{array}$ & Total \\
\hline Grade I & 69 & 15 & $\mathbf{8 4}$ \\
\hline Grade II & 59 & 24 & $\mathbf{1 0 4}$ \\
\hline Grade III & 77 & 15 & $\mathbf{8 2}$ \\
\hline Grade IV & 13 & 03 & $\mathbf{1 6}$ \\
\hline Grade V & 13 & 03 & $\mathbf{1 6}$ \\
\hline \multicolumn{4}{|c|}{ Table 6. $\mathbf{H D L}<\mathbf{4 0} \mathbf{~ m g \%}$ and severity of Retinopathy } \\
\hline
\end{tabular}

The Chi-square statistic is 38.3008. The p-value is $<0.00001$. The result is statistically significant at $\mathrm{p}<0.05$. 


\begin{tabular}{|c|c|c|c|}
\hline Retinopathy & $\begin{array}{c}\text { VLDL > 40 } \mathbf{~ m g \% ~}= \\
\mathbf{1 8 5}\end{array}$ & $\begin{array}{c}\text { VLDL < 40 mg\% } \\
\mathbf{= 1 1 7}\end{array}$ & $\begin{array}{c}\text { Total } \\
\mathbf{3 0 2}\end{array}$ \\
\hline Grade I & 62 & 22 & $\mathbf{8 4}$ \\
\hline Grade II & 75 & 29 & $\mathbf{1 0 4}$ \\
\hline Grade III & 40 & 42 & $\mathbf{8 2}$ \\
\hline Grade IV & 04 & 12 & $\mathbf{1 6}$ \\
\hline Grade V & 04 & 12 & $\mathbf{1 6}$ \\
\hline \multicolumn{3}{|c|}{ Table 7. VLDL > 40 mg\% and severity of Diabetic } \\
Retinopathy
\end{tabular}

The Chi-square statistic is 33.8473. The p-value is $<0.00001$. The result is statistically significant at $\mathrm{p}<0.05$.

\begin{tabular}{|c|c|c|c|}
\hline Retinopathy & $\begin{array}{c}\text { Cholesterol }>200 \\
\mathrm{mg} \%=226\end{array}$ & $\begin{array}{c}\text { Total } \\
\text { Cholesterol } \\
<200 \mathrm{mg} \%=76\end{array}$ & $\begin{array}{c}\text { Total } \\
\mathbf{3 0 2}\end{array}$ \\
\hline Grade I & 63 & 21 & 84 \\
\hline Grade II & 76 & 28 & 104 \\
\hline Grade III & 66 & 16 & 82 \\
\hline Grade IV & 11 & 05 & 16 \\
\hline Grade V & 10 & 06 & 16 \\
\hline
\end{tabular}

The Chi-square statistic is 3.1705. The p-value is .529709 . The result is not statistically significant at $\mathrm{p}<0.05$.

\begin{tabular}{|c|c|c|c|}
\hline Retinopathy & $\begin{array}{c}\text { TG } \mathbf{2 0 0} \mathbf{~ m g \%} \\
\mathbf{= 2 5 6}\end{array}$ & $\begin{array}{c}\text { TG }<\mathbf{2 0 0} \\
\mathbf{m g \% = 4 6}\end{array}$ & Total 302 \\
\hline Grade I & 73 & 11 & $\mathbf{8 4}$ \\
\hline Grade II & 88 & 16 & $\mathbf{1 0 4}$ \\
\hline Grade III & 72 & 10 & $\mathbf{8 2}$ \\
\hline Grade IV & 12 & 04 & $\mathbf{1 6}$ \\
\hline Grade V & 11 & 05 & $\mathbf{1 6}$ \\
\hline \multicolumn{4}{|c|}{ Table 9. Serum Triglycerides and Diabetic Retinopathy } \\
\hline
\end{tabular}

The Chi-square statistic is 5.2464 . The p-value is .262934 . The result is not significant at $\mathrm{p}<0.05$.

\begin{tabular}{|c|c|c|c|c|}
\hline $\begin{array}{c}\text { Sl. } \\
\text { No. }\end{array}$ & Variable & $\begin{array}{c}\text { Chi-square } \\
\text { Statistic }\end{array}$ & P-value & $\begin{array}{c}\text { Significance } \\
\text { at p }<\mathbf{0 . 0 5}\end{array}$ \\
\hline 1. & $\begin{array}{c}\text { Female } \\
\text { preponderance }\end{array}$ & 1.61 & 0.806991 & Not Significant \\
\hline 2. & $\begin{array}{c}\text { Duration of DM } \\
>9 \text { years }\end{array}$ & 0.8111 & 0.936949 & Not Significant \\
\hline 3. & HbA1c & 10.751 & 0.550754 & Not Significant \\
\hline 4. & $\begin{array}{c}\text { Fasting Blood } \\
\text { Sugar }\end{array}$ & 12.0226 & $\mathrm{P} 0.443867$ & Not Significant \\
\hline 5. & LDL $>100 \mathrm{mg} \%$ & 13.9401 & $\mathrm{P} 0.007489$ & Significant \\
\hline 6. & HDL $<40 \mathrm{mg} \%$ & 38.3008 & $\mathrm{P}<0.00001$ & Significant \\
\hline 7. & VLDL $>40 \mathrm{mg} \%$ & 33.8473 & $<0.00001$ & Significant \\
\hline 8. & $\begin{array}{c}\text { Total } \\
\text { Cholesterol }\end{array}$ & 3.1705 & 0.529709 & Not Significant \\
\hline 9. & $\begin{array}{c}\text { Serum } \\
\text { Triglycerides }\end{array}$ & 5.2464 & 0.262934 & Not Significant \\
\hline \multicolumn{5}{|c|}{ Table 10. Statistical Summary } \\
\hline
\end{tabular}

\section{Statistical Analysis}

Descriptive statistics were used to present the findings. Chisquare test of association was used to study the association between severity of retinopathy and different variables under study.

\section{DISCUSSION}

As diabetic retinopathy is one of the major causes of visual disability, assessing the risk factors will add an immense value to the study.

There is a female preponderance among cases of diabetic retinopathy. Similar findings were observed in several studies in India and abroad, though there is no statistical significance for female preponderance.

We correlated the duration of diabetes and severity of retinopathy. Though majority of the patients of DR have a diabetic history of $>9$ years, the correlation has no statistical significance.

In our present study, glycosylated haemoglobin (HbA1c) in correlation with different grades of diabetic retinopathy showed P-value of 0.550754 , which is not statistically significant. CURES Eye Study(13) with linear trends in prevalence of Diabetic retinopathy showed statistical significance ( $\mathrm{P}$-value $<0.001)$.

In a study conducted by Maberley DAL et al in 2007, it was found that poor glycaemic control was associated with increased risk of retinopathy in Diabetics.(14) In Rajiv Raman et al study, a strong association of $\mathrm{HbA1c}$ with sight threatening Diabetic retinopathy (P-value $<0.001$ ) was found.(15)

Concerning lipid profile, in our study HDL (<40 mg\%), LDL (> $100 \mathrm{mg} \%$ ) and VLDL (> $40 \mathrm{mg} \%$ ) showed high significance and correlated with the severity of Diabetic retinopathy ( $\mathrm{p}$-value $<0.05$ ) and Total Cholesterol and Triglyceride levels did not correlate with severity of Diabetic retinopathy. In Rahman et al study, HDL was significantly lower in patients with NPDR.

In Gnaneswaran et al study, TC and LDL were significantly higher in Diabetic retinopathy patients.(16)

In our study, high Fasting blood sugar did not correlate with the severity of diabetic retinopathy.

In a Chinese study, both FBG and higher HbA1c were found to be independent risk factors for Diabetic Retinopathy (DR) and Sight-Threatening Diabetic Retinopathy (STDR).(17)

In our study, duration of Diabetes mellitus did not correlate with severity of retinopathy. Many studies correlated development of DR with duration of diabetes mellitus.(18)

\section{Abbreviations \\ DR: Diabetic Retinopathy. NPDR: Non-proliferative Diabetic Retinopathy, LDL: Low Density Lipoproteins, HDL: High Density Lipoproteins, VLDL: Very Low Density Lipoproteins, HbA1c: Glycosylated Haemoglobin, NPDR: Non-proliferative Diabetic Retinopathy.}

\section{CONCLUSION}

$\mathrm{HDL}<40 \mathrm{mg} \%$, LDL > $100 \mathrm{mg} \%$ and VLDL > $40 \mathrm{mg} \%$ levels have significant correlation with different grades of retinopathy. This also denotes that these values are related to the severity of Diabetic retinopathy, Chi-square test with pvalue of $<0.05$. HbA1c values and High Fasting blood sugar did not correlate with severity of retinopathy.

\section{REFERENCES}

[1] Joshi SR, Parikh RM. India - diabetes capital of the world: now heading towards hypertension. J Assoc Physicians India 2007;55:323-4. 
[2] Kumar A, Goel MK, Jain RB, et al. India towards diabetes control: key issues. Australas Med J 2013;6(10):524-31.

[3] Rema M, Pradeepa R. Diabetic retinopathy-an Indian perspective. Indian J Med Res 2007;125(3):297-310.

[4] Wild S, Roglic G, Green A, et al. Global prevalence of diabetes: estimates for the year 2000 and projections for 2030. Diabetes Care 2004;27(5):1047-53.

[5] R\&B legend Gladys Knight Sings praises of early detection and management of diabetes. Schaumberg (IL), Prevent Blindness America, 2003.

[6] Ciulla TA, Amador AG, Zinman B. Diabetic retinopathy and diabetic macular edema: patho-physiology, screening and novel therapies. Diabetes Care 2003;26(9):2653-64.

[7] Agroiya P, Philip R, Saran S, et al. Association of serum lipids with diabetic retinopathy in type 2 diabetes. Indian J Endocrinol Metab 2013;17(Suppl 1):S335-S7.

[8] Cetin EN, Bulgu Y, Ozdemir S, et al. Association of serum lipid levels with diabetic retinopathy. Intl J Ophthalmol 2013;6(3):346-9.

[9] Kanski JJ, Bowling B. Retinal vascular disease. In: Kanski JJ, edr. Clinical ophthalmology - a systematic approach. 7th edn. London: Elsevier Saunders 2011: p. 533-91.

[10] Javadi MA, Katibeh M, Rafati N, et al. Prevalence of diabetic retinopathy in Tehran province: a populationbased study. BMC Ophthalmol 2009;9:12.

[11] Phadnis P, Kamble MA, Daigavane S, et al. Prevalence and risk factors - hemoglobin A1c, serum magnesium, lipids and microalbuminuria for diabetic retinopathy: a rural hospital based study. Journal of DMIMSU 2017;12(2):121-32.
[12] Niveditha H, Yogitha C, Liji P, et al. Clinical correlation of hba1c and diabetic nephropathy with diabetic retinopathy. Journal of Evolution of Medical And Dental Sciences 2013;2(49):9430-5.

[13] Rema M, Premkumar S, Anitha B, et al. Prevalence of diabetic retinopathy in urban India: The Chennai Urban Rural Epidemiology Study (CURES) eye study, I. Invest Ophthalmol Vis Sci 2005;46(7):2328-33.

[14] Maberley DA, Hollands H, Chang A, et al. The prevalence of low vision and blindness in a Canadian inner city. Eye (Lond) 2007;21(4):528-33.

[15] Raman R, Verma A, Pal SS, et al. Influence of glycosylated hemoglobin on sight-threatening diabetic retinopathy: a population-based study. Diabetes Res Clin Practice 2011;92(2):168-73.

[16] Gnaneswaran S, Vinodhini VM, Kuberan D, et al. Dyslipidemia and diabetic retinopathy in a rural population. Int $\mathrm{J}$ Res Pharmaceut Biomed Sci 2013;4(3):829-32.

[17] Liu Y, Yang A, Tao L, et al. Risk factors of diabetic retinopathy and sight-threatening diabetic retinopathy: a cross-sectional study of 13,473 patients with type 2 diabetes mellitus in mainland China. BMJ Open 2017;7(9):e016280.

[18] Karadeniz ZS, Yilmaz TM. Duration of diabetes and prevalence of diabetic retinopathy: Istanbul Diabetic Retinopathy Study-IDRS results 1. Diabetes \& Metabolic Syndrome: Clinical Research \& Reviews 2007;1(1):43-8. 